\title{
Defining Blackness in Colombia
}

\section{Peter Wade}

\section{(2) OpenEdition}

\section{Journals}

Electronic version

URL: https://journals.openedition.org/jsa/10783

DOI: 10.4000/jsa. 10783

ISSN: $1957-7842$

\section{Publisher}

Société des américanistes

\section{Printed version}

Date of publication: 23 July 2009

Number of pages: 165-184

ISSN: 0037-9174

\section{Electronic reference}

Peter Wade, "Defining Blackness in Colombia", Journal de la Société des américanistes [Online], 95-1

2009, Online since 10 June 2014, connection on 03 September 2022. URL: http://

journals.openedition.org/jsa/10783; DOI: https://doi.org/10.4000/jsa.10783

All rights reserved 


\title{
DEFINING BLACKNESS IN COLOMBIA
}

\author{
Peter WADE *
}

This paper looks at the complex relationship between concepts employed by social scientists and those used in everyday practice and discourse, arguing that the standard ideas about how ideas travel from one domain (state, academe, social movements, everyday usage) to another, and become essentialised or destabilised in the process, are often too simple. Changing definitions of blackness in Colombia, through the process of multiculturalist reform and after, are examined with a view to exploring which categories of actors were influential in shaping these definitions and which were involved in essentialisations and de-essentialisations. [Key words: Afro-Colombians, race, ethnicity, Latin America.]

Définitions des populations noires en Colombie. Cet article explore les relations complexes qui existent entre les concepts utilisés par les chercheurs en sciences sociales et ceux qui sont mobilisés dans la vie et les énoncés quotidiens. Il met en lumière que les idées standards sur les façons dont ces concepts circulent d'une sphère à l'autre (État, universités, mouvements sociaux, rue) et, par là même, s'essentialisent ou se déconstruisent, sont bien trop simples. Les définitions des populations noires en Colombie ont changé avec la réforme qui a institué le multiculturalisme et après. Elles sont ici analysées en tenant compte des catégories d'acteurs qui ont pesé sur leur élaboration et celles qui ont joué un rôle dans les processus d'essentialisation ou l'inverse. [Mots-clés: Afro-colombiens, race, ethnie, Amérique latine.]

La definición de la población negra en Colombia. Ese trabajo examina las relaciones complejas que existen entre los conceptos que utilizan los investigadores de ciencias sociales y los que se usan en la vida cotidiana y en los enunciados de todos los días; insiste en el hecho de que las ideas comunes acerca de las maneras en que estos conceptos pasan de una esfera a la otra (Estado, universidades, movimientos sociales, uso cotidiano) y en que a través de esos movimientos se vuelven esencializados o descontruídos, son demasiado simples. Las definiciones de las poblaciones negras en Colombia han cambiado a raíz de la Reforma que instauró el multiculturalismo y después: aquí se analizan dichas definiciones con especial atención sobre las categorías de actores que influyeron en su elaboración así como las que tuvieron un papel en los procesos de esencialización o de des-esencialización. [Palabras claves: Afro-colombianos, raza, etnia, América latina.]

* University of Manchester, Social Anthropology, School of Social Sciences, Arthur Lewis Building, Manchester M13 9PL, U.K. [peter.wade@manchester.ac.uk].

Journal de la Société des Américanistes, 2009, 95-1, pp. 165-184. (O) Société des Américanistes. 


\section{INTRODUCTION}

The relationship between concepts employed by social scientists and those used in everyday practice and discourse is a complex one. One common narrative is that everyday usage of concepts is initially flexible, but these become univocal and fixed when they enter into academic discourse as analytic concepts. An alternative narrative is that academic usage is flexible and (de-)constructivist and that, when academic concepts enter into the domain of " official » administrative practices and discourses, they become reified and essentialised. A further common story tells of how academic concepts (re-)enter the world of everyday social actors as tools in the struggles of identity politics: social movements may take concepts such as race, ethnicity, culture, gender and use them in " essentialist » ways that are at odds with the social (de-)constructionist approach of the social sciences, whose practitioners tend to see such concepts as flexible, contextdependent constructs (Restrepo 2004).

I am not convinced that these narratives work. Giddens (1990, p. 311) identified the increasing reflexivity of social knowledge as a consequence of modernity. Knowledge about the social produced by those recognised as « experts » filters into and out of the everyday domain: we are all social theorists at some level and share a common interest in thinking about people's behaviour. People absorb social science's ideas about sociality - and then alter their behaviour in light of those ideas, making the domain of the social a permanently shifting target. With mass communications and literacy, the circle of reflexivity gets tighter and faster. Giddens is right, I think, and it is important that his argument makes no assumptions about who will do what with the concepts in circulation - whether expert or everyday practice has a tendency to essentialise or to be anti-essentialist.

What exists is the circulation, and constant mutation, of ideas and concepts in different social fields in which diverse social actors, with different goals and resources, appropriate and adapt concepts in ways that suit their outlook on the world. It is difficult to tell a simple story about how concepts and categories circulate among the state agents, academics, cultural activists, NGO workers and " ordinary people " who are all involved in the production and circulation of knowledge (Ng'weno 2007; Rappaport 2005; Restrepo 2004). Certain categories may achieve a dominant, indeed hegemonic, status, but they do so through a complex interaction between all these knowledge producers (as one might expect for a process that leads to hegemony, which implies some collective agreement).

In what follows, I will trace changing categories and concepts of blackness in Colombia, showing how the definitions of terms such as black, negro, black community, Afro-Colombian and Afro-descendant have been influenced by everyday usage, academic practice, cultural activism, transnational NGO work, and state practice. I will trace a move from a pre-1990s ambiguity about 
blackness, through the post-1991 domination of the comunidad negra (black community), towards an emerging consensus on definitions of blackness that are inclusive and focus on African heritage and diaspora. I end by arguing that, despite this, the power of mestizaje as a lens to view and think about blackness still remains powerful in Colombian society.

\section{The Ambiguity of BLACKNESS}

As in many other Latin American countries, in post-independence Colombia prior to the late twentieth century, the category negro had no institutional space in state practices governed by liberal ideologies of citizenship, which gave little room to ethnic difference among citizens. Indigenous people were, however, recognised as a specific category. Academics also did not pay attention to black as a category: anthropology focused on indigenous peoples; sociology attended to peasants and social classes; history, while it looked at " slaves », did not encompass « Blacks » (Friedemann 1984).

Yet the category negro existed in everyday practice to refer to categories of people. The geographer Agustín Codazzi referred in the 1850s to la raza negra that lived in the Pacific coastal region of the country, populated mainly by descendants of African slaves. The novelist Tomás Carrasquilla (1858-1940) included references to negros in his works (Wade 1993). In the mid-twentieth century, there was extensive press commentary about the music and dance associated with los negros, which were becoming popular (Wade 2000). The term was not well defined, however. On the one hand, it could be very encompassing, as a term used by the elites to refer to the lower classes in general; on the other hand, it could be quite restrictive, as an insult directed against a particular person. Euphemisms such as moreno (brown) were common and in areas identified by observers as very black, such as the Pacific coastal region, locals referred to themselves as libres (free people) rather than negros (Losonczy 1997).

This fundamental ambiguity in the meaning of the term negro - and by extension other racial or colour terms such as moreno, pardo, mestizo, and blanco - underwrote official images of the nation as a mixed nation in which race was not an important issue. In Brazil, the idea of the country as a racial democracy, which became an official ideology from about the 1930s, was also underwritten by the notion that, although terms such as pardo (brown), preto (black) and negro existed, collective social categories designated by such terms did not.

Academic and state knowledge production concurred in this. The 1950s' UNESCO-sponsored studies of race in Brazil inflicted damage on the image of a Brazilian racial democracy, but they sustained the idea that racial categorisations did not command collective agreement (Harris 1970). The contrast was made 
with the USA, where basic racial categories (black, white, native American) were mostly agreed on. For Colombia, Solaún and Kronus (1973) argued that miscegenation had blurred racial categories, even though discrimination against individual blacks did exist. Nevertheless, such academic studies simultaneously underwrote the existence of the category black by constructing it as a viable object of study.

In state census practice, racial or colour categories disappeared from Colombia in the early twentieth century (Smith 1966). Yet the state in Colombia also reproduced the category « black » by continuously referring to it in, for example, school text books (Wade 2000). In Brazil, the state continued to collect census data using such categories as preto, pardo, blanco and amarelo (yellow, that is, of Asian origin) until 1970, when a colour question was dropped, to be included again in 1980 (Nobles 2000, p. 104). However, Nobles argues, the data were used to make arguments about the progressive mixing and whitening of Brazil.

In short, there was a fundamental ambiguity involved in the constant denial and simultaneously the constant reiteration of blackness as a category, both in everyday and state practices. One might want to argue that the state was imposing visions of homogeneous mestizo national identities. While there is a strong element of truth in this, the state also reproduced blackness (and indigenousness). Academics, while challenging the notion of racial democracy (in Brazil), also reproduced the central notion of the vagueness of the category «black ».

\section{THE EMERGENCE OF BLACK IDENTITY AND HUELLAS DE AFRICANIA}

In Colombia, in the 1970s, various black student cultural activist groups began to form, mainly inspired by US black activism and the anti-apartheid movement (Wade 1995). At about the same time, academic perspectives on black studies also began to change, led by Nina de Friedemann whose anthropological studies on black groups appeared from 1969 (Friedemann 1966-1969). The black activist groups were concerned with many aspects of racism and shared a concern with Friedemann over the " invisibility » of Blacks in Colombia: one of their key concerns was with black identity, its weakness and the failure of people they saw as black to identify as such. They tended to use an inclusive definition of blackness, which interpellated as « black » (negro) people who might not have identified as such.

Friedemann was concerned with invisibility, primarily in academic approaches that wrote black people out of the history and ethnography of the country, and one of her key concerns was with African roots (huellas de africania - traces or imprints of Africanness), a theme that she developed with Jaime Arocha (Arocha 1998b; Friedemann and Arocha 1986). Her intention was to uncover hidden creolised Africanisms (Mintz and Price 1976) in order to challenge 
dominant versions of Colombian culture as mainly European and indigenous in origin. She rejected the erasure of blackness in a society governed by a dominant ideology of mestizo national identity, an ideology that, while it made room for indigeneity as an institutionalised form of otherness, ignored or vilified blacks. In terms of social classifications, the implications of this approach were that people could identify with a hidden African past. She and Arocha, like the black activists, were setting the context for an inclusive definition of blackness as something that was already there, denied, but open to re-discovery, in this case rooted in African-derived culture, rather than racialised appearance.

This said, there was a difference between the academic and activist perspectives. The academics were mainly concerned with "black culture» in rural communities in the Pacific coastal region (Arocha 1999; Friedemann 1974) and some other regions (Friedemann 1976; 1980). The activists were urban dwellers who faced discrimination in education, work and housing markets. In that sense, while they were also concerned with " invisibility ", they were more open to the kind of " race relations » and " racial identities » analysis that was suggested to them by their reading of US sources - and which was also the approach that I broadly adopted (Wade 1993). This point is important in terms of how ideas about blackness developed in the 1990s, when black ethnicity and cultural difference became the dominant tropes, displacing frameworks that looked at (urban) race relations and the operation of racism in a class society (which was the dominant approach in Brazil, for example).

It is not clear exactly what were the connections between Friedemann and the black students who set up the 1970s groups, but at least some of these students became acquainted with the work of Friedemann and were influenced by it. Juan de Dios Mosquera, a founding member of the 1976 student group Soweto, which in 1982 became Cimarrón (or The National Movement for the Human Rights of Black Communities in Colombia), before he started university studies had already met with the Spanish anthropologist Gutiérrez Azopardo who later wrote a pioneering history of black people in Colombia (Gutiérrez Azopardo 1980; Mosquera 1985). Members of the Soweto group read Malcolm X, Martin Luther King, Frantz Fanon and Amílcar Cabral, but they also attended the First Congress of Black Culture of the Americas, held in Cali, in August $1977^{1}$. This congress was organised by the Fundación Colombiana de Investigaciones Folclóricas, directed by the black writer and folklorist Manuel Zapata Olivella, who was an important figure in early studies of black culture in Colombia and linked artistic, academic and activist circles.

The Centre for the Investigation and Development of Black Culture, founded in 1975 by Amir Smith-Córdoba, included among its founders the anthropologist Jaime Atencio Babilonia who had written on black culture (Atencio Babilonia $1973)^{2}$. Friedemann was on the editorial committee of the group's newspaper; Presencia Negra. 
From these few details, it is clear that the circulation of ideas between activists and academics was a complex matter: it is not easy to pin down who was influencing whom. Some of the academics were also activists, while activists participated in academic conferences and also produced books that formed part of the growing bibliography about Blacks in Colombia (Mosquera 1985; SmithCórdoba 1980). The question of who was creating (or not) essentialist definitions of blackness is also a complex one. Smith-Córboda was perhaps operating with an essentialist definition of blackness when he accosted on the street people he identified as black with the salutation, "Hola, negro! " - certainly a strategic essentialism aimed at provoking a reaction. But the notion of huellas de africania implied a form of essentialism by privileging African origins as the basis of black culture, when Colombian black culture was arguably formed as much from European and indigenous inputs as African ones. On the other hand, both Smith-Córdoba and Mosquera operated in practice with quite open ideas about who could form a useful part of their organisations, admitting mestizo and white people. And other academics, in Colombia and beyond, also criticised the Friedemann/Arocha perspective for its focus on Africanism (Restrepo 1998; Wade 1997).

\section{CONSTITUTIONAL REFORM AND LA COMUNIDAD NEGRA}

By 1990, the Friedemann/Arocha perspective was dominant in academic circles and was represented by the 1990 launch of the journal edited by Friedemann, América Negra. The kind of perspective represented by my own work, which took a more political economy approach and looked at dynamic frontier and urban contexts, and by the urban black activists, was an undercurrent: these black urban groups were small and marginal; the translation of my main book did not appear in Colombia until 1997.

This is the context in which the constitutional reforms of 1991 took place, officially recasting Colombia as a pluriethnic and multicultural nation (Arocha 1998a; Ng'weno 2007; Van Cott 2000; Wade 1995). Significant concessions were made to las comunidades negras (black communities) located in the Pacific coastal region of Colombia. Arocha and Friedemann were both involved in the Constituent Assembly that eventually approved the inclusion of Transitory Article 55 relating to black communities. In 1993 Law 70 was approved which developed the TA55's brief outline. Academics such as Arocha were part of negotiations leading to this law, alongside black activists.

The meaning of blackness was recast by these changes, but in ways that had strong continuity with the previous situation. In Law 70, blackness was seen as something that ran through Colombian society as a whole - Blacks were recognised as « an ethnic group » - but the focus of the legislation was the rural black 
communities of the Pacific coastal region, which were allowed to establish collective titles to land. The influence of the dominant academic perspective is evident here, with the emphasis on the ethnic and cultural difference of a black ethnic group centred in a marginal rural area, but the situation was actually much more complex (Ng'weno 2007; Restrepo 1997, 2002; Wade, ed., 2002).

First, there had been no black representative elected to the Constituent Assembly; instead an Emberá indigenous leader based in the Pacific coastal region spoke on behalf of indigenous and black communities in the region, which, he said, shared common problems. This meant that the way blackness was presented as an issue could be elided with the way indigeneity was presented - in terms of rooted, rural and ethnically distinct "communities », whose main concern was with land rights. Already in the Pacific coastal region, black and indigenous communities had been cooperating and forming joint peasant associations and this process was often mediated by the Church. Some black rural leaders were already aligning their interests with indigenous agendas. Also, the state was pre-disposed to " hear 》 an expression of blackness that assimilated it to indigenous models, with which the state had been familiar for many decades. In the process, then, blackness became indigenised (Hooker 2005; Ng'weno 2007; Wade 2002).

Second, black organisations played a significant lobbying role in the process, despite the absence of a representative in the Constituent Assembly. This lobbying was dominated by Pacific coastal organisations: older groups such as Cimarrón were marginal to, indeed overtaken by, these events. Thus agendas related to the interests of Pacific coastal groups, which tended to revolve around land and rural communities, took priority. In addition, the theme of cultural difference and ethnicity was strong. A key post-1991 black organization, Proceso de Comunidades Negras (PCN), is based mainly in the southern Pacific region and has argued in interview that « presenting the situation of Afro-Colombian communities in terms of racial discrimination has little audience » (Pedrosa et al. 1996, p. 251; my translation); instead, an emphasis on cultural difference was seen as more effective. The PCN's website reflects its regional and cultural bias. One of its stated "lines of action " is the recognition of the rights of "la comunidad negra colombiana como grupo étnico " (the Colombian black community as an ethnic group) ${ }^{3}$. On the one hand, this reinforces the idea of a single black community, which has the status of a culturally distinct unit; on the other hand, in practice the PCN's focus on the southern Pacific coast tends to conflate that ethnic group with the black communities of that region.

The concept of the commidad negra has been very powerful in the Pacific coastal region and has implied « the abandonment of the socio-political specificities » (Hoffmann 2004, p. 218) of actual black communities there, which are very diverse, in the name of a more singular and homogeneous black ethnic identity. The state discourse of black community, allied to real resources (land 
titles) attached to that category, and to the social movement discourse of black community ethnicity have all worked together to make comunidad negra into dominant concept - even in zones outside the Pacific coastal region (Cunin 2000; Ng'weno 2007).

In sum, the recasting of the meaning of blackness - a recasting that has constrained the compass of that flexible term-emerged out of a complex interaction between academics, activists, the state and, indeed, the Church. As in previous times, there were notable links between academics and activists. Restrepo (1997, p. 311) notes: « certain important activists in the movement of black communities that emerged out of the National Constituent Assembly, and who have subsequently participated directly or as "acompañantes" [associates] to the new organisations, had a university background in anthropology and were acquainted with the academic discussions that had been taking place since the 1980s ». Key figures in PCN, such as Carlos Rosero and Libia Grueso still have close links with anthropologists such as Arturo Escobar and Eduardo Restrepo (Grueso et al. 1998), while Grueso has an MA in Political Studies (Grueso 2000).

If the end result of Law 70 was a definition of blackness that is constraining, as it ruralises and indigenises blackness and prioritises ethnic difference over racism, this is not a simple process of essentialisation and reification that can be laid at the door of a particular set of actors. I would argue that the state's priorities had a decisive influence, because it suited the state's neo-liberal agendas to limit the compass of the law and to focus on the Pacific coastal region where massive development plans were under way (Escobar 1997, 2003; Ng'weno 2007; Wade 2002) - a conjuncture of neo-liberalism and multiculturalism that has been analysed by Hale $(2002 ; 2005)$. But existing academic frameworks, allied with social movement agendas and conjunctures, laid the basis for such a move and facilitated the dominance of this notion of blackness.

However, this definition of blackness is also contested. Black movements outside the Pacific coastal region and in urban areas have been active in pursuing their own claims and developing the parts of Law 70 that apply to all « black communities » in Colombia. One example is the successful attempt by a local Cimarrón leader in the Caribbean coastal city of Santa Marta to get official recognition for the existence of a " black community » there, which, under Law 70 , would allow a representative from the community to sit on the city council's education committee. The attempt was turned down by a succession of courts, but allowed by the Constitutional Court in 1996, legimitising a « black community » in a way apparently outside the compass of Law 70 (Cunin 2003). Other examples from the Cauca valley are described by $\mathrm{Ng}$ 'weno (2007).

The PCN's website has also recently seen postings of documents that refer to the Magdalena Medio (the middle reaches of the Magdalena river valley that transects the country) - even if these are still marginal to the vast weight of material on the website ${ }^{4}$. And the PCN also has as one of its " lines of action » 
the struggle against racism ${ }^{5}$. Anecdotally, it is interesting that Carlos Rosero, a PCN leader, mentioned to me in 2001 that the theme of racism, which had been seen by the PCN as having "little audience ", was being reconsidered by the organisation. Hoffmann also notes « a reorientation of the ethnic debate towards the anti-discrimination struggle » (Hoffmann 2004, p. 221).

\section{The Hegemony OF « AFro »}

If the particular constructions of Law 70 have been subject to criticism - and this is not to mention the fact that land titles that have been established are often rendered worthless by the low-intensity warfare that is being waged in the Pacific coastal region by guerrillas, paramilitaries and the army -, then an emerging and perhaps more durable hegemony is being established around the notions of Afro-Colombian and Afro-descendant. The term comunidades negras, while still current and still potentially problematic in relation to, say, urban contexts, has been joined and to some extent displaced by the terms afrocolombiano and more recently afrodescendiente. The basis for these was already set with the notion of huellas de africania and this was strengthened by the emphasis on black cultural distinctiveness in the constitutional reform process. This was reinforced by the fact that, in the mid 1990s, major development agencies began to take an interest in what they called Afro-Latins and/or Afro-descendants: the Inter-American Development Bank (IDB), the World Bank, the UN and the Inter-American Foundation all became involved in researching and funding Afro-Latin communities ${ }^{6}$. This is arguably a North American way of defining blackness, but, as we have seen, the emphasis on africania was not a simple North American import into Colombian academic discourse - which is not to say North American concepts were not influential, just that they were not simple imported determinants. The Portuguese term afrodescendente was coined in Brazil in 1996, by the black feminist activist Sueli Carneiro, and became common usage especially after the 2001 Durban conference on racism, appearing in Colombia around the same time (Mosquera et al. 2002).

One sign of the dominance of these terms has been their appearance in the Colombian census. The 1993 census broke new ground in Colombia by including the question « Do you belong to any ethnic [group], indigenous group or black community? ", followed by the subsidiary question, for those who answered in the affirmative, « To which one? ». People self-identifying as indigenous had been counted before, but this was the first attempt to include any other « ethnic group » or « black communities ». The result was absurd: only $1.5 \%$ of people identified as belonging to " a black community », a category that had only just been legitimised by the state (Flórez et al. 2001). Later, the state came up with different estimates for the black population as a percentage of the national total, ranging from $16 \%$ to $25 \%$ (Wade 2002, p. 6). 
Meanwhile, the National Department of Statistics (DANE) was engaged in a debate about how to change the census question, and pilot studies were carried out, some of them funded by the World Bank ${ }^{7}$. Government agencies, multilateral institutions and transnational academic networks worked in complex relationships to construct new ways of thinking about blackness. Influential in this was the work of a project, funded by the French and Colombian states and involving academics from both countries; key figures included the Colombian sociologist Fernando Urrea Giraldo and the French sociologist Olivier Barbary ${ }^{8}$. The researchers on the project were critical of the category comunidad negra, which they argued only had meaning - and then only limited - in relation to the Pacific coastal region and they took a much more inclusive approach to defining blackness, based on phenotype and self-identification (Barbary and Urrea Giraldo 2004a; Flórez et al. 2001). Urrea Giraldo and Barbary were involved in the extensive consultations and debates with DANE about how to construct a new census question about ethnicity. In the end, the 2005 census included question 33:

According to your culture, pueblo or physical features, are you or are you recognised as being:

1. Indigenous? (To which pueblo indigena do you belong?)

2. Rom?

3. a raizal? [a neologism meaning a rooted person, a native] of San Andrés and Providencia [Colombian islands in the Caribbean]

4. a palenquero of San Basilio? [someone from the village of San Basilio, an old palenque, or runaway slave settlement of colonial origin]

5. black, mulatto, Afro-Colombian or Afro-descendant?

6. none of the above? ${ }^{9}$

It is clear that the conceptual category of blackness behind the question is a broad one, attempting to construct a single category of black people which leans in the direction of a North American definition and does not worry about whether blackness is construed through culture, physical appearance or pueblo, a vague term meaning village, town, nation or people. The figure of $10.5 \%$ given by DANE for the Afro-Colombian population was calculated to include categories 3,4 and 5 in the question above ${ }^{10}$.

The census question has reinforced a view in which blackness has become an inclusive and expansive category, based in part on some identification with " afro ». Although many commentators see afrocolombianos and comunidad negra as being more or less synonymous terms, both based on an ethnic identity - and indeed the two terms are often used interchangeable by cultural activists and state officials - there is clearly a departure here from the more limited idea of the commidad negra, implicitly located in the rural Pacific region, a departure 
that responds better to the nature of the census as a national enterprise. This notion of blackness reinforces the hegemony of an inclusive definition of blackness which is also a relatively simple definition of blackness (despite the complexity of the question): that is, either you are black (and palenquero and raizal are sub-categories of black) or you are indigenous or you are " none of the above ».

I think the " afro » element of these designations is becoming increasingly distant from Africa itself and from ideas about « real » Africanisms. Instead, " afro " now invites people to identify with a globalised, mass-mediated culture of blackness, associated with certain images and styles - of music, bodily comportment, dress - and realised to a great degree through practices of consumption (Sansone 2003; Wade 1999).

All these census terms fit into the new official multiculturalism of Colombia which creates and depends on a clear set of ethnic categories. It is clear that mestizos and whites (those who would classify as "none of the above ") are the unmarked category: one has to positively identify as " different », as ethnically distinct. This is a multiculturalism in which the " multicultural » are those who are ethnically different from the national norm. In the construction of the hegemony of this view of blackness, the state, academics, cultural activists and transnational agencies such as the World Bank have worked together - which is not to say they have been in cahoots, but rather that their disparate and at times conflicting projects converge around this notion of blackness.

When one asks who is reifying and essentialising categories, the answers are complex. The state did a lot of work to legitimate a restrictive concept of comunidad negra, only to undermine that with the 2005 census question. Some activists were building political projects around the idea of the Pacific coastal black community and its land rights; others (typically more urban) were tapping into notions of a global, diasporic blackness. Some academics were pushing the notion of huellas de africania, others were constructing more inclusive concepts of afro and, as I shall show, also restating the indeterminacy of that very category, linking this to the importance of mestizaje.

\section{BLACKNESS AND MESTIZAJE}

The Franco-Colombian project included studies in Cali, which had received large currents of black in-migration from the Pacific coastal region. A key 1998 survey gathered demographic, social and economic data in order to measure racial segregation and discrimination in the housing and labour markets (Barbary and Urrea Giraldo 2004a). I think this work is having a paradoxical effect. On the one hand, the statistical work effected the construction of a relatively simple black category of "Afro-Colombian » which allowed comparison with non-Afro-Colombians on various different measures. In addition, the 
survey work on how people identified themselves and others indicated that, in the urban environment, a conceptual classification separated los negros from the rest. This was agreed on by significant sectors of the black and non-black population of the city. A common image was that of the ghetto. This racial identification contrasted with the ethnic-territorial identification based on the idea of the comunidad negra, located in rural areas of the Pacific coastal region (Barbary 2001; Barbary et al. 2004). The explicit theoretical orientation of this work was away from " culturalist » models, which saw Afro-Colombians as constituting ethnic comunidades negras in the Pacific coastal region, towards a " materialist perspective » on " ethnic-racial processes » which focused on phenotype, selfand other-identification, and on experiences of racism (Barbary and Urrea Giraldo 2004b, p. 30). Of course, it is significant that Barbary and Urrea Giraldo were closely involved in the consultations around defining a new ethnic question for the 2005 census.

On the other hand, the survey differentiated between negro, mulato, blanco and mestizo and showed how both interviewers (instructed to assign people to one of the four categories) and respondents (asked to classify themselves by skin colour in an open-ended way) distinguished between a number of categories. It also showed that the idea of the ghetto did not correspond to a US ghetto-style reality in terms of residential segregation, despite the appearance of small areas that were very predominantly black (Barbary 2004). In addition, the data showed that the classifications of interviewers and respondents did not match: interviewers tended to classify people as black and mulatto (and indeed white) more than respondents classified themselves with these or similar terms, although women were $20 \%$ more likely to identify as negra than men (Barbary et al. 2004, p. 262); respondents used mestizo-like categories (e.g., the term trigueña, wheatcoloured) more than the interviewers (Barbary et al. 2004; Flórez et al. 2001, p. 46). These results parallel similar results from Brazil (Sansone 2003; Telles 2004) and confirm ideas about the ambiguity of racial classifications in Latin America that have been around for decades (Harris 1970; Solaún and Kronus 1973).

Cunin's work in Cartagena, on the Caribbean coast of Colombia, also demonstrates that blackness can be a highly ambiguous category that exists in relation to ideas about mixture (Cunin 2004b). On the one hand, the idea of blackness revolves strongly around the image of the palenquero from San Basilio, the " real » site and embodiment of blackness, and which fits into both images of comunidad negra and afrocolombiano (especially since palenquero culture is said to retain strong traces of africania). In this sense, blackness has a stable, if narrow, referent. On the other hand, blackness is a much more ambiguous category: negro is often seen as a term connoting marginality and is one people avoid, especially when talking to a white anthropologist (Cunin 2004a); "Afro-Colombian » has little leverage among young, black, working-class people. People in the city avoid 
talking about race, colour, blackness, etc., except when it comes to stigmatising other people as black or naming palenqueros as the « real Blacks ». Cunin uses the concept of "mestizo competence » to describe how people deploy flexible and ambiguous categorisations in strategies of social placement.

All this shows that the categories that connote blackness can be both stable and unstable depending on context. Inclusive, clear categories (AfroColombians, los negros, the ghetto) can co-exist with much vaguer and more contextually shifting classifications. This is the co-existence that I tried to capture in my work on blackness and race mixture and which I think is still a key part of the picture, despite the evident changes that have occurred in the construction of a more inclusive and apparently clearly defined Afro-Colombian, Afrodescendant or black category. In sum, while a significant trend in academic work was towards the construction of an inclusive - and potentially essentialist - category of afro, the same body of work was also demonstrating the ambiguity of that category.

\section{Conclusion}

I have traced how an increasingly inclusive and clear concept of blackness has emerged in Colombia, spurred strongly by the post-1991 reforms and social movements, but with important roots in the academic and activist work of previous decades. In the wake of Law 70, a strong element of black identity was the comunidad negra, based on ethnic difference and territorial claims and, while this is still very strong, supported by Law 70, it is being complemented by a more encompassing category of " afro ", also supported by state multiculturalism and the census, which goes beyond the Pacific coastal region and is especially important in urban settings. A countervailing but subordinate tendency is the recognition of the practical ambiguity of that category - something that has greatly exercised the Brazilians in the implementation of affirmative action programmes and racial quotas (Maio and Santos 2005), but that has been ignored in Colombia, despite the presence of some incipient affirmative action programmes in, for example, university admissions (Cunin 2000; Wade 2006, p. 114). This recognition is evident in some academic circles and in everyday life; it is less evident in state circles, activist organisations and transnational NGO and funding circles.

The story traced here indicates that concepts circulate in complex ways around and between academics, state officials and policy-makers, cultural activists, transnational NGO workers and « everyday people » (meaning people who - while everyone is a social theorist of a sort - don't make it their business to think in a specialised, theoretical and systematic way about categories such as "black »). I don't think there is a simple story to tell about who reifies and essentialises the categories in circulation. The emergence of the concept of 
comunidad negra and the " afro » category has been the result of a consensus, at some level, among lots of different people for whom these categories had useful effects and could be made to work in productive ways, often for rather different purposes. They are both concepts that can be reified and essentialised by academics, cultural activists and the state, but they are also destabilised by people in those same categories.

Even certain instances of the state - which arguably encompasses the agents and agencies most likely to produce simple, constraining concepts of blackness to fit into official multiculturalist and developmentalist agendas - work to destabilise concepts. The decision to include an ethnic question in the census undermines the comumidad negra category that has arguably been a useful one for the state in its dealings in the Pacific coastal region. The question, however, constructs another essentialisation of blackness as including all those who are linked to blackness and who are Afro-Colombian or Afrodescendant, even if they may also be Indo-Colombian or Euro-Colombian (or Indodescendant and Eurodescendant) at the very same time. The Constitutional Court decision that I referred to above also undermined the category of comunidad negra even as it reiterated it: the category could now be found as an emergent, fragmented, « imagined community » in the city of Santa Marta. If nothing else, this indicates that «the state » operates in multiple and possibly contradictory ways: what happens in the Department of Statistics or the Constitutional Court may be very different from what happens in the Department of Planning or the Ministry of the Interior.

Perhaps the most problematic category of actor, especially for the anthropologist, are the cultural activists, in part because they seem to be the people most closely related to academics, often moving in academic circles, most disposed to use academic knowledge as a source of legitimation, most likely to reify and instrumentalise concepts of race, culture, ethnicity, history, etc., most likely to question the anthropologist's ethical stance and interrogate his/her political commitment. Restrepo $(2004 ; 2005$, pp. 175-211) argues that popular ways of conceptualising the relationships between academics and social movements are too simple: academics either support or undermine activists with their knowledge (or an alternative ethical position is that they do neither and simply present « the truth »). He argues that neither dominant nor subordinate groups necessarily appropriate academic knowledge in a direct and simple fashion: both " groups " are heterogeneous entities made up of subjects who are themselves constituted by the articulation of multiple forces.

Rappaport's recent work on indigenous intellectuals and their associated colaboradores and solidarios is revealing here (Rappaport 2005). She argues against a simple view of indigenous intellectuals as essentialising and reifying. She argues they are open to seeing culture as emergent and oriented to future political projects, rather than rooted in the past. Indigenous social movements are highly heterogeneous and there may be all kinds of essentialisation going on there 
- as there is in the practice of some state officials and NGO actors - but this is not the whole picture by any means. Anthropologists often agonise over their relationship to social movements and worry that their agendas of deconstruction conflict with the agendas of cultural vindication and political mobilisation of social movement activists. This is undoubtedly a potential problem, given the real differences in political and social positioning that may exist between academics and activists, but $\mathrm{I}$ think both academics and social movement activists are a more heterogeneous bunch than implied by this particular narrative of the production of academic knowledge. *

* Manuscrit reçu en août 2007, accepté pour publication en février 2008.

\section{NOTES}

I am grateful to Sara Le Menestrel and Véronique Boyer for inviting me to participate in their colloquium and to Odile Hoffimann and Paul Schor for their comments on the original paper.

1. Interview with Juan de Dios Mosquera (Pereira, Colombia, 10 August 1992).

2. Interview with Amir Smith-Cordoba (Bogotá, Colombia, 27 July 1992).

3. http://www.renacientes.org/index.php?option=com_content\&task=view\&id=17\&Itemid=47, accessed 22 August 2007.

4. See the Afrocolombianos pages of the Libros Libres section of the PCN website, www.renacientes.org.

5. http://www.renacientes.org/index.php?option=com_content\&task=view\&id=17\&Itemid=47, accessed 31 August 2006.

6. The IDB did a series of country reports on Afro-Latinos in 1995-1996 (Sánchez 1996). The World Bank organised in June 2000 and 2001 two inter-agency consultations on Afro-Latins, which included the IDB and the Inter-American Dialogue think-tank and the Inter-American Foundation. The WV also provided funding for land titling processes in the Pacific cosatal region (Ng'weno 2007). See also the UN report on Afro-descendants (Santos Roland 2002).

7. See http://www.iadialog.org/iac/eng/events/SocialInclusionandColombianCensusDane.htm and the link there to the relevant World Bank pages.

8. This project was titled «Organización social, dinámicas culturales e identidades de las poblaciones afrocolombianas del pacífico y suroccidente en un contexto de movilidad y urbanización " and was run 1996-2000 by Centro de Investigaciones y Documentación Socioeconómica, Universidad del Valle, Cali, and IRD (Institut de Recherche pour le Développement, Paris). It has resulted in numerous publications (e.g., Agier et al. 1999; Barbary and Urrea Giraldo 2004a; Hoffmann 2004).

9. See http://www.dane.gov.co/files/censo2005/cuestionario.pdf, accessed 22 August 2007.

10. See http://www.dane.gov.co/files/censo2005/etnia/sys/colombia_nacion.pdf, accessed 22 August 2007.

\section{REFERENCES CITED}

AgIER Michel et al.

1999 Tumaco: haciendo ciudad, Instituto Colombiano de Antropología/Institut de Recherche pour le Développement/Universidad del Valle, Bogotá. 
Arocha Jaime

1998a «Inclusion of Afro-Colombians: an unreachable goal », Latin American Perspectives, 25 (3), pp. 70-89.

1998 b "Los ombligados de Ananse », Nómadas, 9, pp. 201-209.

1999 Ombligados de Ananse: hilos ancestrales y modernos en el Pacífico colombiano, Centro de Estudios Sociales/Facultad de Ciencias Humanas, Universidad Nacional de Colombia, Bogotá.

Atencio Babilonia Jaime

1973 "Hacia un marco histórico-cultural en las relaciones de negros e indios », Revista de Humanidades de la Universidad del Valle, 7, pp. 83-91.

BARBARY Olivier

2001 "Identidad y ciudadanía afrocolombiana en Cali y la región Pacífica: pistas estadísticas para una interpretación sociológica ", Scripta Nova. Revista Electrónica de Geografia y Ciencias Sociales, 94 (22) [http://www.ub.es/geocrit/sn-94-22.htm].

2004 "El componente socio-racial de la segregación residencial en Cali », in Olivier Barbary and Fernando Urrea Giraldo (eds), Gente negra en Colombia: dinámicas sociopolíticas en Cali y el Pacifico, CIDSE/Universidad del Valle, IRD/Colciencias, Medellín, pp. 157-194.

Barbary Olivier, Héctor F. Ramírez, and Fernando Urrea Giraldo

2004 «Identidad y ciudadanía afrocolombiana en el Pacífico y Cali », in Olivier Barbary and Fernando Urrea Giraldo (eds), Gente negra en Colombia: dinámicas sociopoliticas en Cali y el Pacífico, CIDSE/Universidad del Valle, IRD/Colciencias, Medellín, pp. 245-282.

Barbary Olivier, and Fernando Urrea Giraldo (eds)

2004a Gente negra en Colombia: dinámicas sociopolíticas en Cali y el Pacífico, CIDSE/Universidad del Valle, IRD/Colciencias, Medellín

2004b "Introducción », in Olivier Barbary and Fernando Urrea Giraldo (eds), Gente negra en Colombia: dinámicas sociopoliticas en Cali y el Pacífico, CIDSE/Universidad del Valle, IRD/Colciencias, Medellín, pp. 21-65.

Cunin Elisabeth

2000 "Relations interethniques et processus d'identifaction à Carthagène (Colombie) ", Cahiers des Amériques Latines, 33, pp. 127-153.

2003 Identidades a flor de piel. Lo "negro » entre apariencias y pertenencias: categorías raciales y mestizaje en Cartagena, María Carolina Barreto and Guillermo Vargas (translators), Instituto Colombiano de Antropología e Historia.Universidad de los Andes/Instituto Francés de Estudios Andinos/Observatorio del Caribe Colombiano, Bogotá.

2004a «De la esclavitud al multiculturalismo: el antropólogo entre identidad rechazada e identidad instrumentalizada ", in Eduardo Restrepo and Axel Rojas (eds), Conflicto e (in) visibilidad: retos de los estudios de la gente negra en Colombia, Universidad del Cauca, Popayan, pp. 141-156.

2004b Métissage et multiculturalisme en Colombie. Le "noir » entre apparences et appartenances, L'Harmattan/IRD, Paris. 


\section{Escobar Arturo}

1997 «Cultural politics and biological diversity: state, capital and social movements in the Pacific coast of Colombia ", in Richard G. Fox and Orin Starn (eds), Between resistance and revolution: cultural politics and social protest, Rutgers University Press, New Brunswick, N. J, pp. 40-64.

2003 "Displacement, development and modernity in the Colombia Pacific », International Social Science Journal, 55 (1), pp. 157-167.

Flórez Carmen Elisa, Carlos Medina and Fernando Urrea Giraldo

2001 Understanding the cost of social exclusion due to race or ethnic background in Latin America and Caribbean countries, Inter-American Development Bank, Washington.

\section{Friedemann Nina de}

1966-1969 «Contextos religiosos en un área negra de Barbacoas, Nariño », Revista Colombiana de Folclor, 4 (10), pp. 63-83.

1974 "Minería del oro y descendencia: Güelmambí, Nariño », Revista Colombiana de Antropología, 16, pp. 9-86.

1976 "Negros, monopolio de la tierra, agricultores y desarrollo de plantaciones de azúcar en el valle del río Cauca », in Nina de Friedemann (ed.), Tierra, tradición y poder en Colombia: enfoques antropológicos, Colcultura, Bogotá, pp. 143-167.

1980 Ma Ngombe: guerreros y ganaderos en Palenque, Carlos Valencia Editores, Bogotá.

1984 "Estudios de negros en la antropología colombiana », in Jaime Arocha and Nina de Friedemann (eds), Un siglo de investigación social: antropología en Colombia, Etno, Bogotá, pp. 507-572.

Friedemann Nina de and Jaime Arocha

1986 De sol a sol: génesis, transformación y presencia de los negros en Colombia, Planeta, Bogotá.

GidDEns Anthony

1990 The consequences of modernity, Polity Press, Cambridge.

\section{GruEso Libia}

2000 El proceso organizativo de comunidades negras en el Pacifico sur Colombiano, MA thesis, Pontificia Universidad Javeriana.

Grueso Libia, Carlos Rosero and Arturo Escobar

1998 "The process of black community organizing in the southern Pacific coast of Colombia ", in Sonia Alvarez, Evelina Dagnino and Arturo Escobar (eds), Cultures of politics, politics of cultures: re-visioning Latin American social movements, Westview, Boulder, pp. 196-219.

\section{GutiérRez Azopardo Ildefonso}

1980 La historia del negro en Colombia, Editorial Nueva América, Bogotá. 
HaLe Charles R.

2002 "Does multiculturalism menace? Governance, cultural rights and the politics of identity in Guatemala ", Journal of Latin American Studies, 34, pp. 485-524.

2005 «Neoliberal multiculturalism: the remaking of cultural rights and racial dominance in Central America ", PoLAR: Political and Legal Anthropology Review, 28(1), pp. 10-28.

HARris Marvin

1970 "Referential ambiguity in the calculus of Brazilian racial terms ", Southwestern Journal of Anthropology, 27, pp. 1-14.

\section{HOFFManN Odile}

2004 Communautés noires dans le Pacifique colombien. Innovations et dynamiques ethmiques, IRD/Karthala, Paris.

HOOKER Juliet

2005 "Indigenous inclusion/black exclusion: race, ethnicity and multicultural citizenship in contemporary Latin America ", Journal of Latin American Studies, 37 (2), pp. 285-310.

Losonczy Anne-Marie

1997 Les saints et la forêt: rituel, société et figures de l'échange entre Noirs et Indiens Emberá (Chocó, Colombie), L'Harmattan, Paris.

\section{Maio Marcos Chor and Ricardo Ventura Santos}

2005 "Política de cotas raciais, os "olhos da sociedade" e os usos da antropologia: o caso do vestibular da Universidade de Brasília (UnB) », Horizontes Antropológicos, 11 (23), pp. 181-214.

MinTz Sidney and Richard Price

1976 An anthropological approach to the Afro-American past: a Caribbean perspective, Institute for the Study of Human Issues, Philadelphia.

Mosquera Claudia, Mauricio Pardo and Odile Hoffmann (eds)

2002 Afrodescendientes en las Américas. Trayectorias sociales e identitarias. 150 años de la abolición de la esclavitud en Colombia, Universidad Nacional de Colombia/Instituto Colombiano de Antropología e Historia/Institut de Recherche pour la Développement/Instituto Latinoamericano de Servicios Legales Alternativos, Bogotá.

Mosquera Juan de Dios

1985 Las comunidades negras de Colombia, Editorial Lealon, Medellín.

NG'weno Bettina

2007 Turf wars: territory and citizenship in the contemporary state, Stanford University Press, Stanford.

NoBLEs Melissa

2000 Shades of citizenship: race and the census in modern politics, Stanford University Press, Stanford. 
Pedrosa Alvaro et al.

1996 «Movimiento negro, identidad y territorio: entrevista con la Organización de Comunidades Negras ", in Arturo Escobar and Alvaro Pedrosa (eds), Pacifico: ¿desarrollo o biodiversidad? Estado, capital y movimientos sociales en el Pacífico colombiano, CEREC, Bogotá, pp. 245-265.

RAPPAPORT Joanne

2005 Intercultural utopias: public intellectuals, cultural experimentation and ethnic pluralism in Colombia, Duke University Press, Durham.

RESTREPO Eduardo

1997 "Afrocolombianos, antropología y proyecto de modernidad en Colombia ", in María Victoria Uribe and Eduardo Restrepo (eds), Antropología en la modernidad: identidades, etnicidades y movimientos sociales en Colombia, Instituto Colombiano de Antropología, Bogotá, pp. 279-320.

1998 "Avatares del negro en la antropología en Colombia », Nómadas, 9, pp. 191-199.

2002 "Políticas de la alteridad: etnización de "comunidad negra" en el Pacífico sur colombiano ", Journal of Latin American Anthropology, 7 (2), pp. 34-58.

2004 «Esencialismo étnico y movilización política en las relaciones entre saber y poder ", in Olivier Barbary and Fernando Urrea Giraldo (eds), Gente negra en Colombia: dinámicas sociopoliticas en Cali y el Pacífico, CIDSE/ Universidad del Valle, IRD/Colciencias, Medellín, pp. 227-244.

2005 Políticas de la teoría y dilemas en los estudios de las colombias negras, Editorial Universidad del Cauca, Popayán.

SÁNCHEz Margarita

1996 Comunidades de ancestría africana: en Costa Rica, Honduras, Nicaragua, Argentina, Colombia, Ecuador, Perú, Uruguay y Venezuela, Inter-American Development Bank, Washington D.C.

SANSONE Livio

2003 Blackness without ethnicity: constructing race in Brazil, Palgrave Macmillan, Houndmills.

SAntos Roland Edna Maria

2002 Prevention of discrimination: report of the regional seminar on Afrodescendants in the Americas (La Ceiba, Honduras, 2124 March 2002), Sub-Commission on the Promotion and Protection of Human Rights/Commission on Human Rights/Economic and Social Council, United Nations, [s. 1.].

\section{SMith-Córdoba Amir}

1980 Cultura negra y avasallamiento cultural, MAP Publicaciones, Bogotá.

Sмiтн T. Lynn

1966 "The racial composition of Colombia», Journal of Inter-American Studies, 8, pp. 213-235. 
Solaún Mauricio and Sidney Kronus

1973 Discrimination without violence: miscegenation and racial conflict in Latin America, John Wiley and Sons, New York.

Telles Edward E.

2004 Race in another America: the significance of skin color in Brazil, Princeton University Press, Princeton.

Van CotT Donna Lee

2000 The friendly liquidation of the past: the politics of diversity in Latin America, University of Pittsburgh Press, Pittsburgh.

WADE Peter

1993 Blackness and race mixture: the dynamics of racial identity in Colombia, Johns Hopkins University Press, Baltimore.

1995 "The cultural politics of blackness in Colombia ", American Ethnologist, 22 (2), pp. 342-358.

1997 Gente negra, nación mestiza: las dinámicas de las identidades raciales en Colombia, Ana Cristina Mejía (translator), Ediciones Uniandes/Ediciones de la Universidad de Antioquia/Siglo del Hombre Editores, Instituto Colombiano de Antropología, Bogotá.

1999 "Working culture: making cultural identities in Cali, Colombia », Current Anthropology, 40 (4), pp. 449-471.

2000 Music, race and nation: música tropical in Colombia, University of Chicago Press, Chicago.

2002 "The Colombian Pacific in perspective ", Journal of Latin American Anthropology, 7 (2), pp. 2-33.

2006 "Afro-Latin studies: reflections on the field », Latin American and Caribbean Ethmic Studies, 1 (1), pp. 105-124.

WADE Peter (ed.)

2002 "Black identity and social movements in Latin America: the Colombian Pacific region », Journal of Latin American Anthropology, special issue, 7. 